\title{
ASESMEN OTENTIK : MENGHADAPI ERA GLOBALISASI (Menjawab Tantangan Internal dan Eksternal Pendidikan)
}

\author{
Hairida $^{1}$ \\ Email : hairida_fkipuntan@yahoo.co.id
}

\begin{abstract}
Abstrak
Makalah ini ditulis berdasarkan pengamatan analitik kritis secara deskriptif. Di dalam berbagai analisis mengenai trend kehidupan dalam era globalisasi, termasuk pula trend di dalam pengembangan sistem pendidikan, kehidupan manusia mempunyai dimensi bukan hanya dimensi domestik tetapi global. Merupakan hal yang logis jika sistim pendidikan perlu dibenahi agar meningkat kualitasnya dan dihasilkan masyarakat yang cerdas. Asesmen dalam pembelajaran merupakan salah satu aspek yang dapat digunakan untuk meningkatkan kualitas pendidikan bangsa Indonesia, yang pada akhirnya dapat digunakan untuk menghadapi persoalan globalisasi.
\end{abstract}

Kata kunci: globalisasi, asesmen otentik, tantangan internal, tantangan eksternal

\section{A. Pendahuluan}

Globalisasi hadir dengan membawa segala macam fenomena baru yang tidak terpikir, tergapai dan membuat masyarakat terpana. Menurut Djiwandono (dalam Sindhunata (Ed), 2000:105). Globalisasi telah menciptakan dunia yang semakin terbuka dan saling ketergantungan antarnegara dan antarbangsa. Semua negara pada prinsipnya akan menjadi terbuka terhadap pengaruh globalisasi. Globalisasi merupakan suatu kondisi yang tidak terelakkan oleh semua umat manusia di bumi ini. Ia telah menyentuh hampir seluruh aspek kehidupan.

Globalisasi yang ditandai arus gelombang era ketiga sebagaimana menurut ilmuwan barat, telah memberi dampak yang cukup luas dalam kehidupan moral masyarakat. Pengaruh dan kesan yang dibawa oleh berbagai isme melalui media teknologi komunikasi dan informatika telah memberi kesan sosial-moral yang amat parah. Dampak yang ditimbulkan telah melanda jiwa dan jati diri masyarakat di perkotaan maupun di luar

${ }^{l}$ Hairida : adalah dosen Jurusan Pendidikan MIPA FKIP UNTAN 
perkotaan. Tingginya frekuensi pemberitaan tentang kerusakan sosial dan moral memperkuat fenomena ini, antara lain bentuk perlakuan tidak bermoral seperti pembunuhan, perkawinan keluarga, pelacuran, gang-sterisme, alkoholisme, perjudian, ketagihan obat-obat terlarang hingga isu vandalisme juga telah melanda masyarakat Indonesia

Tidak kalah pentingnya persoalan globalisasi adalah kenyataan bahwa globalisasi menyebabkan arus yang begitu cepat dan tidak dapat dibendung dari begitu banyak dan beragam infromasi. Istilah "globalisasi" merupakan salah satu contoh saja dari upaya terkemuka dari beberapa pihak untuk memahami atau memaknai perubahan besar-besaran ini. Menghadapi dunia yang sedang mengalami perubahan besar pada saat ini, seluruh sendi kehidupan harus dibenahi. Tetapi, dengan berbagai variasi maknanya, globalisasi tetap tidak memuaskan semua pihak yang terlibat atau terkena dampak perubahan ini. Kennedy (1995: xiv) mengungkapkan bahwa jumlah penduduk Indonesia tahun 2025 diramalkan akan berjumlah 263 juta. Sumber Daya Manusia yang cukup potensial ini sangat berguna untuk menghadapi perubahan. Untuk menjawab tantangan, ancaman dan bahaya dari perubahan yang berskala global ini, salah satu cara yang dapat dipersiapkanbangsa kita adalah membenahi sistem pendidikan. Peran pendidikan sangatlah strategis dalam membangun bangsa (nation building), karena pendidikan tidak saja memiliki fungsi yang hakiki dalam mempersiapkan sumber daya manusia yang akan menjadi aktor-aktor dalam menjalankan fungsi dari berbagai kehidupan, tetapi juga merupakan suatu daya upaya bertumbuhnya budi pekerti (kekuatan batin, karakter, pikiran, intelektual) dari tubuh peserta didik. Pendidikan sebagai suatu pembentuk watak/kepribadian juga harus dapat mempersiapkan sumber daya yang handal dan dapat dipertanggung jawabkan.

Pembukaan UUD 45 dengan kata "mencerdaskan kehidupan bangsa" menjadi tanda bahwa kecerdasan menjadi penting. Menurut Musnir (Sindhunata (Ed), 2000:65) bila konsep pendidikan diturunkan dalam konsep mendidik maka konsep mendidik akan mengandung arti upaya mencerdaskan manusia atau subyek didik. Oleh karena itu, negara memilki peran untuk memberi pendidikan kepada rakyat untuk mencerdaskan kehidupan bangsa. Masyarakat yang cerdas hanya dapat dihasilkan melalui pendidikan yang berkualitas. Namun terkadang nilai normatif tidak seindah realitasnya. Cita-cita luhur ini masih jauh dari harapan dan cenderung menjauh dari cita-cita pendidikan itu sendiri. Peringkat Indonesia pada HDI (Human Development Index) tahun 2007/2008 menempati peringkat ke107. Indikator dari HDI meliputi pendapatan per kapita, akses pendidikan , dan akses terhadap kesehatan. Artinya, peringkat HDI tersebut menjadi suatu 
indikator dari kualitas pendidikan di Indonesia masih rendah. Terkait dengan hal tersebut, dalam sistem pendidikan di Indonesia masih banyak yang harus dibenahi. Oleh karena itu diperlukan langkah-langkah untuk meningkatkan kualitas pendidikan bangsa kita. Edmond mengemukakan enam langkah yang dapat mempengaruhi sistem pendidikan yaitu: (1) kepemimpinan yang kuat; (2) suasana pembelajaran; (3) lingkungan yang tertata rapi; (4) harapan tinggi di kalangan siswa untuk berprestasi; (5) penekanan pendidikan pada keterampilan dasar dan (6) sistem evaluasi yang sistematis dan sinambung (Doni Koesoema, 2007:300). Pendapat Doni ini mengisyaratkan bahwa asesmen dalam pembelajaran merupakan salah satu aspek yang dapat digunakan untuk meningkatkan kualitas pendidikan bangsa Indonesia, yang pada akhirnya dapat digunakan untuk menghadapi persoalan globalisasi.

Kenyataannya dalam melaksanakan penilaian hasil belajar sains di sekolah terdapat kecenderungan dari para pendidik untuk mengutamakan penggunaan tes (paper and pencil test) sebagai satu-satunya alat ukur yang terpenting dalam proses pendidikan. Padahal tes itu sendiri memiliki keterbatasan, karena tidak mampu mengukur kemampuan peserta didik yang sebenarnya dan hanya terfokus pada beberapa aspek saja. Tes ini juga tidak memberi kesempatan kepada peserta didik untuk menunjukkan kemampuan atau potensi masing-masing.

Kondisi yang telah dipaparkan di atas membawa konsekuensi logis pada para pendidik untuk dapat mengubah pola pikir dan perilaku para peserta didik agar lebih baik dan mampu menciptakan peserta didik yang etismoralis, kreatif serta inovatif dalam menghadapai tantangan internal dan ekstrenal dunia pendidikan di era globalisasi. Banyak hal yang perlu dipikirkan dan ditekuni pendidik secara serius, misalnya sistem penilaian yang disesuaikan dengan tuntutan masyarakat di era globalisasi, sehingga dapat meningkatkan kualitas pendidikan.

\section{B. Apa itu Globalisasi?}

Kata globalisasi seringkali kita baca dan dengar. Globalisasi tidak dapat kita hindari. Globalisasi memiliki hubungan dengan peningkatan keterkaitan dan ketergantungan antarbangsa dan antarmanusia di seluruh dunia melalui perdagangan, investasi, perjalanan, dan bentuk-bentuk interaksi yang lain sehingga batas-batas suatu negara menjadi semakin sempit. Globalisasi berlangsung di semua bidang kehidupan seperti bidang ideologi, politik, ekonomi, sosial budaya, pertahanan keamanan dan lain- lain, sehingga istilah globalisasi tidak tunggal. Di sisi lain, ada yang melihat globalisasi sebagai sebuah proyek yang diusung oleh negara-negara adikuasa, 
sehingga bisa saja orang memiliki pandangan negatif atau curiga terhadapnya.

Jamli, dkk (2005) mendefinisikan globalisasi pada hakikatnya adalah suatu proses dari gagasan yang dimunculkan, kemudian ditawarkan untuk diikuti oleh bangsa lain yang akhirnya sampai pada suatu titik kesepakatan bersama dan menjadi pedoman bersama bagi bangsa- bangsa di seluruh dunia. Menurut Ali Idrus (2009:46), globalisasi selain menghadirkan ruang positif untuk hidup mudah, nyaman, murah, indah dan maju, tetapi juga menghadirkan keresahan, penderitaan dan penyesatan. Robertson (1992: 8) mendefinisikan globalisasi adalah : "... the compression of the world and the intensification of consciousness of the world and the intensification of consciousness of the world as a whole."

Kehadiran globalisasi tentunya membawa pengaruh bagi kehidupan suatu negara termasuk Indonesia. Pengaruh tersebut meliputi dua sisi yaitu pengaruh positif dan pengaruh negatif. Pengaruh globalisasi di berbagai bidang kehidupan seperti kehidupan politik, ekonomi, ideologi, sosial budaya dan lain- lain akan mempengaruhi nilai-nilai nasionalisme terhadap bangsa (Tri Darmayati, 2008).

Pengaruh positif globalisasi terhadap nilai-nilai nasionalisme dapat dilihat dari:

1) Globalisasi politik, yaitu pemerintahan dijalankan secara terbuka dan demokratis. Tanggapan positif tersebut berupa rasa nasionalisme terhadap negara menjadi meningkat.

2) Globalisasi ekonomi, yaitu terbukanya pasar internasional, meningkatkan kesempatan kerja dan meningkatkan devisa negara.

3) Globalisasi sosial budaya, yaitu kita dapat meniru pola berpikir yang baik seperti etos kerja yang tinggi dan disiplin dan Iptek dari bangsa lain yang sudah maju untuk meningkatkan kemajuan bangsa yang pada akhirnya memajukan bangsa dan akan mempertebal rasa nasionalisme kita terhadap bangsa.

Pengaruh negatif globalisasi terhadap nilai-nilai nasionalisme, yaitu :

1) Globalisasi mampu meyakinkan masyarakat Indonesia bahwa liberalisme dapat membawa kemajuan dan kemakmuran. Jika hal tesebut terjadi akibatnya rasa nasionalisme bangsa akan hilang.

2) Hilangnya rasa cinta terhadap produk dalam negeri karena banyaknya produk luar negeri (seperti Mc Donald, Coca Cola, Pizza Hut,dll.) membanjiri di Indonesia.

3) Mayarakat kita khususnya anak muda banyak yang lupa akan identitas diri sebagai bangsa Indonesia, 4) adanya kesenjangan sosial yang tajam antara yang kaya dan miskin, karena adanya persaingan bebas dalam 
globalisasi ekonomi, 5) munculnya sikap individualisme yang menimbulkan ketidakpedulian antarperilaku sesama warga.

Dengan demikian, definisi globalisasi bergantung dari sisi mana orang melihatnya. Ada yang memandangnya sebagai suatu proses social, atau proses sejarah, atau proses alamiah yang akan membawa seluruh bangsa dan negara di dunia makin terikat satu sama lain, mewujudkan suatu tatanan kehidupan baru atau kesatuan ko-eksistensi dengan menghilangkan batasbatas geografis, ekonomi dan budaya masyarakat.

\section{Pendidikan di Era Globalisasi}

Kemajuan ilmu pengetahuan dan teknologi yang disertai dengan globalisasai, membawa dampak tersendiri bagi dunia pendidikan. Pendidikan tidak mungkin menisbikan proses globalisasi yang akan mewujudkan masyarakat global ini. Perubahan-perubahan yang terjadi secara global menyebabkan perubahan gaya hidup di masyarakat Indonesia.

Cara yang yang paling efektif dalam menghadapi era globalisasi adalah melalui peningkatan kualitas pendidikan. Selanjutnya, menurut Muhibbin (2003:1) pendidikan pada dasarnya adalah usaha sadar untuk menumbuhkembangkan potensi sumber daya manusia peserta didik dengan cara mendorong dan memfasilitasi kegiatan belajar mereka. Kedua pendapat di atas memberikan suatu pengertian bahwa pendidikan yang berkualitas bukan hanya mengembangkan intelegensi peserta didik, tetapi mengembangkan seluruh potensi yang dimiliki oleh peserta didik, sehingga mampu bersaing dalam masyarakat global.

Secara filosofis Ki Hadjar Dewantara (1977:14) menyatakan bahwa pendidikan merupakan daya upaya untuk memajukan bertumbuhnya budi pekerti (kekuatan batin, karakter), pikiran (intellect) dan tubuh anak. bagianbagian itu tidak boleh dipisahkan agar kita dapat memajukan kesempurnaan hidup, yakni kehidupan dan penghidupan anak-anak yang kita didik selaras dengan dunianya. Pengertian pendidikan oleh Ki Hajar Dewantara tersebut mengisyaratkan bahwa melalui pendidikan hendak diwujudkan kesempurnaan hidup peserta didik dengan memiliki berbagai kecerdasan, baik kecerdasan spiritual, emosional, sosial, dan intelektual. Kecerdasan ini sangat penting dimiliki oleh peserta didik dalam rangka peningkatan kualitas pendidikan untuk menghadapi globalisasi.

Mengingat pentingnya peningkatan kualitas pendidikan, pemerintah menganggap perlu dibuat payung hukum tentang Sistem Pendidikan Nasional, antara lain Undang-Undang RI Nomor 20 Tahun 2003 tentang Sistem Pendidikan Nasional Bab 1 Pasal 1 Ayat 1 bahwa pendidikan didefiniskan sebagai usaha sadar dan terencana untuk mewujudkan suasana 
belajar dan proses belajar agar peserta didik secara aktif mengembangkan potensi dirinya untuk memiliki kekuatan spiitual keagamaan, pengendalian diri, kepribadian, kecerdasan, akhlak mulia, serta keterampilan yang diperlukan dirinya, masyarakat, bangsa dan negara.

Sehubungan dengan peningkatan kualitas pendidikan, pemerintah tidak pernah berhenti dalam membangun dan membenahi sektor pendidikan, karena adanya tantangan jaman dan menyadari permasalahan-permasalahan yang timbul akibat globalisasi. Tantangan yang dihadapi pendidikan dewasa ini tidak hanya tantangan internal, melainkan tantangan eksternal juga. Tilaar (2004:9-14) mengemukakan bahwa sistem pendidikan nasional tidak terlepas dari tugas dan tanggung jawab untuk memberikan jawaban yang tepat terhadap tantangan internal dan internal pendidikan. Tantangan internal pendidikan yaitu masalah kesatuan bangsa, demokratisasi pendidikan, desentralisasi manajemen pendidikan, dan kualitas pendidikan, yang diuraikan sebagi berikut.

1. Masalah kesatuan bangsa

Masalah ini muncul dapat disebabkan memudarnya kesatuan bangsa dari sebagian masyarakat. Selain itu, munculnya perasaan kecewa karena hasil pembangunan di suatu daerah yang menimati bukan orang daerah, justru orang pusat

2. Demokratisasi pendidikan

Masalah demokratisasi pendidikan muncul karena keinginan yang sangat kuat untuk kehidupan demokrasi yang dimaknai sebagai kehidupan yang menghargai potensi individu.

3. Desentralisasi manajemen pendidikan

Masalah ini muncul karena penyusunan dan penentuan kurikulum dianggap memberatkan peserta didik.

4. Kualitas pendidikan

Masalah ini muncul karena upaya peningkatan kualitas guru dari sisi peningkatan kualifikasi akademik semata-mata hanya untuk memperoleh kesejahteraan material.

Tantangan eksternal atau lazim disebut tantangan global meliputi pendidikan yang kompetitif dan Inovatif serta Identitas (Tilaar, 2004: 15-17). Kehidupan global dengan pasar bebasnya yang kompetitif memerlukan manusia yang berkualitas, yang bisa bersaing di dalam arti yang baik, sehingga hasil karya atau produk-produk yang dihasilkan dapat berkompetisi. Untuk itu diperlukan kemampuan berkompetisi. Kemampuan kompetisi tergantung juga kepada pribadi-probadi yang inovatif. Pendidikan di era globalisasi harus dapat mengembangkan kemampuan inovatif, sehingga dihasilkan peserta didik yang kreatif dan inovatif. Amabile (1983:31) 
mengidentifikasikan kreativitas dan inovasi sebagai sesuatu yang dapat dilihat dari hasil (creative product) dan/atau dapat dilihat dari proses seseorang menjadi kreatif (creative process). Lebih lanjut dikemukakan, bahwa yang lebih penting adalah identifikasi kegunaan (fruit) dan kemungkinan keterlaksanaan sebagai sesuatu yang kreatif dari proses atau subproses, produk atau respon.

Kehidupan global akan melahirkan kebudayaan global. Budaya global selain dapat membuka cakrawala pemikiran anggota masyarakat, tetapi juga kemungkinan akan masuknya unsur-unsur budaya global yang negatif, yang dapat merusak generasi muda bangsa Indonesia. Misalnya narkoba, di mana Indonesia telah merupakan suatu jaringan persilangan perdagangan internasional yang dimungkinkan oleh semakin mudahnya komunikasi inetrnasional. Oleh sebab itu, semakin penting adanya suatu kesadaran akan identitas sebagai suatu bangsa. Tugas pendidikan nasional ialah mengembangkan identitas peserta didik agar dia bangga menjadi bangsa Indonesia yang dengan penuh percaya diri memasuki kehidupan global sebagai seorang bangsa Indonesia yang berbudaya.

\section{Perspektif tentang Asesmen (Penilaian) dan Evaluasi}

Implementasi KTSP dalam dunia pendidikan perlu diikuti dengan perubahan sistem pembelajaran yang benar-benar memberikan ruang gerak kepada peserta didik untuk mengembangkan potensi dirinya agar memiliki kekuatan spiritual keagamaan, pengendalian diri, kepribadian, kecerdasan, akhlak mulia, serta keterampilan yang diperlukan dirinya, masyarakat, bangsa, dan negara. Demikian pula dengan tuntutan profesionalitas, terus berkembang dan semakin menuntut guru untuk dapat mencapainya. Kemampuan memahami peserta didik, bidang akademik, bidang pembelajaran dan bidang sosial merupakan sejumlah tuntutan yang harus dipenuhi guru pada saat ini. Setiap kemampuan tersebut dapat dijabarkan dalam sub-sub kemampuan. Kemampuan melakukan penilaian (asesmen) dan evaluasi merupakan bagian dari profesionalisme guru dalam melakukan proses pembelajaran atau pendidik

an.

Asesmen didefinisikan sebagai proses memperoleh informasi yang digunakan dalam membuat keputusan tentang siswa, kurikulum dan program, kebijakan pendidikan (Nitko, 2001: 4). Proses yang berkaitan dengan membuat keputusan tentang siswa misalnya mencakup usaha-usaha pengamatan atas tugas tertulis siswa, jawaban siswa atas pertanyaabnpertanyaan yang diajukan dalam kelas, performa siswa atas tes-tes yang dibuat guru dan tes-tes yang terstandardisasi. 
Asesmen merupakan bagian yang tidak bisa dipisahkan dari pengajaran dan pembelajaran. Terlepas dari pentingnya asesmen dan jumnlah waktu yang yang dibutuhkan untuk melakukan penilaian, para ahli memperkirakan lebih dari sepertiga waktu profesionalisme guru adalah guru seringkali merasa sulit mempersiapkan dirinya untuk menghadapi penilaianpenilaian tersebut (Stiggins, 2004, 2005 dalam Jacobsen, et al., 2009:290)

Meningkatkan kualitas pembelajaran merupakan fungsi utama asesmen, sehingga asesmen dan evaluasi penting dalam kehidupan siswa. Jika kita mengenang kembali masa-masa sekolah, tentu masih ingat saat menerima kembali hasil tes atau rapor. Apa yang dirasakan? Senang dan cemas, itulah yang dirasakan. Hampir sering terdengar pertanyaan siswa kepada temannya, 'Nilaimu berapa?'. Mungkin pertanyaan kesenangan siswa, "Apakah tes itu akan muncul dalam ulangan besok?". Pertanyaanpertanyaan semacam ini menunjukkan bahwa asesmen dan evaluasi penting dalam kehidupan siswa. Selain itu, asesmen dan evaluasi juga penting bagi orang tua siswa. Literatur (Airasian, 2005 dalam Arends, 2007: 217) menunjukkan bahwa kekhawatiran orang tua siswa tentang nilai dan kinerja dapat digunakan oleh guru untuk meperbaiki pembelajaran siswa.

Istilah asesmen biasanya merujuk pada seluruh rentang informasi yang dikumpulkan dan disintesiskan oleh guru tentang siswa-siswanya maupun tentang kelasnya atau informasi tentang pengajaran guru (Arends, 2008:217). Informasi tentang siswa dapat diperoleh secara formal atau informal. Secara formal seperti PR, tes, dan laporan tertulis, sedangkan secara informal seperti observasi dan pertukaran verbal. Selanjutnya dinyatakan bahwa evaluasi biasanya mengacu pada proses membuat keputusan (judgment), menetapkan nilai (value), atau memutuskan tentang worth (manfaat). Evaluasi adalah proses sistematik mengumpulkan, menganalisis, dan menginterpretasi informasi untuk menentukan sampai tingkat mana siswa mencapai sasaran pembelajaran yang lebih menekankan pada tipe kinerja realistik dan kompleks. Evaluasi menjawab pertanyaan: "How good?" (Linn \& Grounlund, 1995: 5).

Tes adalah salah satu teknik asesmen yang digunakan untuk mengumpulkan informasi tentang seberapa banyak yang diketahui siswa tentang topic tertentu. Memberi nilai adalah sebuah tindakan evaluatif, karena guru menempatkan value pada informasi yang diperoleh dari tes itu.

\section{E. Jenis-jenis Asesmen di Era Globalisasi}

Perkembangan pemahaman akhir-akhir ini bahwa meskipun ada peningkatan skor terstandarisasi, namun siswa tidak otomatis menjdi siswa yang lebih berpendidikan atau berpengetahuan. Menurut Ronis (2011:1), 
Kesenjangan antara hasil pengetesan (testing) tradisional dan kenyataan mengenai apa yang diketahui, dan dapat atau tidak dapat dilakukan siswa sekolah menengah mendukung ketidak-tertarikan pada metode asesmen pembelajaran tradisional siswa, dan telah memberi dorongan dan momentum untuk melakukan gerakan asesmen otentik.

Menurut Santrock (2008: 648), asesmen tradisional biasanya menggunakan paper and pencil test dimana siswa mengerjakan soal pilihan, dan memberi jawaban pendek. Pada bagian lain, Santrock (2008:656), menyatakan bahwa asesmen alternatif menawarkan kepada siswa lebih banyak pilihan dibandingkan asesmen tradisional. Palomba \& Bantai (1999) (dalam Santrock, 2008:657) menyatakan bahwa asesmen tradisonal menggunakan tes yang sering kali di luar konteks dunia nyata. Asesmen tradisional (misal obyektif tes) tidak dapat digunakan untuk menilai penalaran ilmiah yang mendalam. Tes obyektif juga sulit mengukur pemahaman tentang hakekat sains dan proses bagaimana saintis bekerja (Marzano, 1994; NRC, 2000).

Kini berkembang trend untuk mengases siswa dengan soal-soal yang lebih mencerminkan realitas, misalnya menggunakan authentic assessment (asesmen otentik), yaitu penilaian yang secara langsung mengukur performa siswa melalui tugas-tugas "kehidupan nyata" (Worthen, 1993: 444-454). Para pereformasi pendidikan seperti Stiggins (2004) dan Jeannie Oaker (2007) (dalam Jacobsen, et al., 2009:294) mengatakan bahwa "kinerja yang bermakna di berbagai lingkup dunia nyata lebih dapat menangkap kekayaan pemahaman siswa tentang begaimana mereka dapat menerapkan pengetahuan daripada yang dapat dilakukan dengan menguji "bits and pieces" seperti yang dilakukan dengan prosedur-prosedur asesmen konvensional (dalam Arends, 2007). Beberapa contoh penilaian autentik dalam IPA:

- Menjelaskan masalah kehidupan nyata, seperti mengapa pakaian cenderung "menempel" bersama-sama ketika baru keluar dari pengering (IPA).

- Merancang dan mengadakan sebuh eksperimen untuk mengukur pengarugh-pengaruh yang berbeda dalam perkembanganm tumbuhtumbuhan.

- Mempresentasikan karya tulis hasil pengamatan di lapangan tentang pencemaran udara kepada teman-teman sebaya.

Contoh asesmen otentik di atas menunjukkan bahwa asesmen otentik dapat mengukur kemampuan peserta didik dalam berbagai macam kemungkinan pemecahan masalah yang dihadapi dalam situasi atau konteks dunia nyata. Aspek belajar yang meliputi domain kognitif, afektik dan psikomotorik dapat diukur melalui asesmen otentik, baik yang tampak 
sebagai hasil akhir dari suatu proses pembelajaran, maupun berupa perubahan dan perkembangan aktivitas, dan perolehan belajar selama proses pembelajaran berlangsung (di dalam atau di luar kelas/laboratorium).

Terdapat dua bentuk penilaian otentik, yaitu performance assessment dan penggunaan portofolio-portofolio (Jacobsen, et al., 2009:301-302). Beberapa ahli menyatakan bahwa istilah authentic assessment kadangkadang digunakan untuk menjelaskan performance assessment karena tugastugas asesmennya yang lebih dekat dengan kehidupan nyata. Istilah alternative assessment digunakan juga untuk performance assessment karena merupakan alternative untuk assessment tradisional paper and pencil test (Popham, 1994:142). Jadi ada istilah lain yang berkaitan dengan penilaian otentik, yaitu performance assessment dan alternative assessment. Tetapi istilah itu tidak dapat dipertukarkan. Asesmen alternatif menyoroti perbedaan terhadap tes tradisional kertas dan pensil; sedangkan asesmen otentik menekankan aplikasi praktis tugas-tugas dalam setting dunia-nyata (Linn \& Grounlund, 1995:238). Berikut ini dipaparkan tentang performance assessment dan alternative assessment.

\section{a. Performance assessment (Asesmen Kinerja)}

Performance Assessment direkomendasikan para ahli pendidikan (Linn \& Grounlund, 1995; NRC, 2000; Zainul, 2001) sebagai asesmen otentik untuk menilai kemampuan siswa dalam menerapkam konsep pada situasi nyata. Performance assessment merupakan penilaian terhadap perolehan, penerapan pengetahuan dan keterampilan yang menunjukkan kemampuan siswa dalam proses maupun produk (Herman et al., 1992; Zainul, 2001).

Performance assessment menginginkan peserta didik untuk mendemonstrasi-kan beberapa tugas tertentu, seperti melakukan eksperimen, menginterpretasi solusi suatu masalah, membuat dan mempresentasikan laporan hasil observasi. Menurut Arends (2007:242) dalam performance assessment mengharuskan peserta didik untuk mengerjakan beragam tugas selama beberapa hari dan bukan tugas-tugas yang dapat diases selama beberapa menit. Selain itu, performance assessment juga merupakan upaya untuk mengukur berbagai macam keterampilan dan proses intelektual yang kompleks. Dua metode untuk mengukur performance assessment

Yang umum digunakan adalah checklist dan skala-skala penilaian. Checklist merupakan deskripsi tertulis tentang dimensi-dimensi yang harus disajikan tentang performa yang dapat diterima. Skala penilaian merupakan deskripsi tertulis tentang dimensi-dimensai dan skala-skala 
nilai dimana tiap dimensi dinilai. Skala ini memungkinkan adanya penilaian kualitas yang lebih seksdama daripada penilaian dengan checklist.

\section{b. Alternative Assessment (Asesmen Alternatif)}

Penilaian terhadap peserta didik tidak hanya mencakup penilaian perubahan atau perkembangan perilaku belajar setelah peserta didik menempuh suatu pelajaran tertentu. Penilaian terhadap perubahan dan perkembangan diri peserta didik dalam proses pembelajaran seharusnya juga mencakup : kecakapan dan pengetahuan awal (prior knowledge), aktivitas dan kecakapan yang tampak pada siswa selama proses pembelajaran berlangsung di kelas, dan aktivitas pengetahuan/kecakapan siswa yang dilaksanakan dan diperoleh di luar kelas atau di lingkungan sehari-hari.

Format penilaian alternative dapat berupa portofolio. Popham (1994:163) menyatakan bahwa bahwa portofolio dalam pendidikan menunjukkan pada kumpulan setiap pekerjaan siswa yang sistematis. Portofolio juga membutuhkan kinerja sesuai konteks (Arends, 2007:246). Kumpulan hasil pekerjaan siswa misalnya hasil tes, laporan praktikum, laporan hasil observasi di luar kelas, produk, hasil pekerjaan tugas-tugas di kelas dan di rumah, catatan hasil kegiatan mandiri yang terkait dengan bahan pelajaran di sekolah.

\section{F. Penggunaan Asesmen Otentik di Era Globalisasi}

Dalam menghadapi era globalisasi, pendidikan bergeser dari ide back to basic ke arah ide the forward to future basics, yang mengandalkan pada peningkatan kemampuan how to think, how to learn and how to create (TLC). How to think menekankan pada pengembangan critical thinking, how to learn menekankan pada kemampuan untuk bisa secara terus menerus dan mandiri menguasai dan mengolah informasi, dan how to create menekankan pada pengembangan kemampuan untuk dapat memecahkan berbagai problem yang berbeda-beda.

Pendidikan harus dapat mengajak siswa untuk berpikir secara lebih luas dan mendalam mengenai suatu masalah, sehingga dapat berkompetisi. Menurut Pradipto (2007: 121-126) pendidikan seharusnya tidak menekankan pada prestasi dan ranking dalam kelas. Penekanan pada being dan bukan having. Prestasi merupakan sebuah bentuk dari kebudayaan having. Prestasi dan ranking membuat anak hanya belajar untuk nilai, menjadi juara dan mengejar nilai raport saja sedangkan budaya being akan 
mengantarkan anak pada kesadaran dan pemahaman. Untuk itu, sistem asesmen (penilaian) juga perlu dilakukan perubahan atau perbaikan.

Dalam menghadapi era globalisasi, proses belajar seharusnya menghasilkan berbagai kemampuan atau kompetensi. Hasil-hasil belajar meliputi kemampuan yang multidimensi. Untuk itu, asesmen yang digunakan juga harus dapat menilai seluruh aspek hasil belajar peserta didik. Namun, banyak pihak mengeluhkan bahwa sebagian besar peserta didik sekarang ini kurang terampil dan tidak mampu berpikir kritis. Sebagian besar peserta didik tidak mampu berpikir sesuai dengan masalah yang disodorkan kepadanya, dan tidak mampu mencari pemecahan masalahnya dengan cara sendiri. Sementara itu sekolah lebih bergairah untuk melatih anak dengan metode drill, anak dipacu untuk mengerjakan test tertulis berupa tes pilihan berganda, sedangkan tes lain seperti tes lisan (oral test), tes prilaku atau tampilan (performance test) kurang diperhatikan dalam penilaian siswa, sehingga proses pembelajaran hanya terfokus pada aspek kognitif saja, sedangkan pada aspek afektif dan psikomotor masih terabaikan.

Asesmen tradisional dalam pendidikan tidak membuat peserta didik menjadi kritis, kreatif dan inovatif. Menurut Tilaar (2004:52) bangsa yang pendidikannya terus menerus hanya mementingkan hafalan, mengisi ujian multiple choice, menghafal rumus-rumus yang ruwet tetapi tidak inovatif maka dia tidak dapat bersaing. Penilaian otentik dapat digunakan sebagai alternatif dari asesmen tradisional yang selama ini banyak digunakan, untuk menghadapi tantangan internal dan eksternal pendidikan di era globalisasi, yaitu masalah kesatuan bangsa, demokratisasi pendidikan, desentralisasi manajemen pendidikan, dan kualitas pendidikan serta tantangan global. Penilaian otentik menjadi penting dalam proses pembelajaran di era globalisasi karena dapat memberikan informasi lebih banyak tentang kemampuan peserta didik dalam proses maupun produk, bukan sekedar memperoleh informasi tentang jawaban benar atau salah saja.

Dalam asesmen otentik, peserta didik dilibatkan dalam dalam tugastugas yang bermanfaat, penting dan bermakna, dan bersifat pertanyaan terbuka. Hal ini memungkinkan peserta didik menunjukkan kompetensinya dalam berbagai cara. Asesmen otentik terdiri dari tugas yang mencerminkan kehidupan nyata, tantangan antardisiplin ilmu. Asesmen seperti ini akan melatih keterampilan berpikir tingkat tinggi dan penggunaan pengetahuan yang luas peserta didik. Keterampilan ini sangat penting dimiliki oleh peserta didik dalam menghadapi tantangan internal dan eksternal pendidikan di era globalisasi.

Era globalisasi menjadikan dunia terbuka dengan perdagangan bebas dan kerjasama regional memerlukan manusia-manusia yang berkualitas. 
Menurut Tilaar (2004:15) dunia perdagangan dan kehidupan bersama masa depan bukan lagi diisi oleh manusia-manusia yaang solitaire, tetapi manusiamanusia yang dapat bekerja sama (team work). Dalam asesmen otentik, tugas-tugas yang dikerjakan peserta didik bervariasi, ada tugas-tugas yang harus diselesaikan individu dan ada juga tugas-tugas yang harus diselesaikan secara kelompok/kolaboratif. Selain itu, penilaian otentik, akan melatih peserta didik menunjukkan kemampuannya dalam proses maupun produk. Melalui kolaboratif dalam penilaian otentik, pendidik dapat mengembangkan sikap kompetitif yang sehat di kalangan peserta didik. Sikap kompetitif seperti ini akan menghasilkan produk yang berkualitas, karena mereka berusaha secara bersama-sama untuk menampilkan sesuatu yang lebih baik. Pengalaman kolaboratif ini mendorong terciptanya dukungan sosial yang lebih besar daripada pengalaman kompetitif secara individualistik. Sikap kompetitif ini sangat penting dimiliki oleh peserta didik saat harus bersaing dalam memasarkan produk yang dihasilkan. Hal ini sejalan dengan kehidupan demokrasi yang memerlukan manusia-manusia yang kreatif dan inovatif, namun tidak ego dan "menghalalkan" segala macam cara untuk mencapai tujuan. .

Kehidupan global akan melahirkan kebudayaan global. Budaya global selain dapat membuka cakrawala pemikiran anggota masyarakat, tetapi juga kemungkinan akan masuknya unsur-unsur budaya global yang negatif, yang dapat merusak generasi muda bangsa Indonesia. Penilaian otentik bersifat holistik yang mencakup semua aspek dari tujuan pembelajaran, yaitu kognitif, afektif dan psikomotorik. Artinya, asesmen otentik tidak hanya melatih peserta didik aspek kognitif dan psikomotorik untuk memperoleh nilai angka yang tinggi. Aspek sikap juga dapat dilatih dalam penilaian otentik, sehingga perilaku peserta didik menjadi lebih baik dan mampu menjadi peserta didik yang etis-moralis. Dengan demikian, peserta didik tidak mudah terpengaruh dalam berbagai bentuk pergaulan kehidupan dan tidak malu untuk mengakui sebagai bangsa Indonesia di era globalisasi.

\section{G. PENUTUP}

Penggunaan asesmen otentik di era globalisasi merupakan kebutuhan yang mendesak untuk dikembangkan dalam proses pembelajaran yang memenuhi standar nasional pendidikan. Asesmen Otentik merupakan salah satu asesmen yang selalu mengajak siswa untuk berpikir secara lebih luas dan mendalam mengenai suatu kasus. Asesmen seperti ini akan melatih keterampilan berpikir tingkat tinggi dan penggunaan pengetahuan yang luas 
peserta didik, dalam menghadapi tantangan internal dan eksternal pendidikan di era globalisasi.

\section{DAFTAR REFERENSI}

Arends, Richard. 2007. Learning to Teach (Seventh Edition). New York: Mcgraw Hill Companies, inc.

Asmawi Zainul. 2001. Alternative Assessment. Jakarta: UT

Amabile, T.M. 1983. The Social Psychology of Creativity (Springer Series in Social Psychology). New York: Springer-Verlag New York Inc.

Doni Koesoema A. 2007. Pendidikan Karakter: Strategi Mendidik Anak di Zaman Global. Jakarta: PT Grasindo.

Djiwandono, J. Soedjati. 2000. Globalisasi dan Pendidikan Nilai dalam Menggagas Paradigma Baru Pendidikan : Demokratisasi, Otonomi, Civil Society, Globalisasi. Sindhunata (Ed). Yogyakarta:Kanisius.

Drake, Frederick. 2000. Using Alternative Assessment To Improve The Teaching and Learning of History. ERIC: Clearinghouse for Social Studies/Social Science Education.

Idrus, Ali. 2009. Manajemen Pendidikan Global : Visi, Misi dan Adaptasi. Jakarta: Gaung Persada.

Herman, J.L., Aschbacter, P.R., Winters, L. 1992. A practical Guide to alternative Assessment. California: The Regents of the University of California.

Karim, Muhammad. 2009. Pendidikan Kritis Transformatif. Yogyakarta: ArRuzz Media.

Kennedy, Paul. (Terj). 1995. Menyiapkan Diri Menghadapi Abad Ke-21. Jakarta: Yayasan Obor Indonesia.

Ki Hajar Dewantara. 1977. Pendidikan dan Kebudayaan. Yogyakarta. Majelis Luhur Persatuan Taman Siswa.

Linn, R.L. \& Gronlund, N.E. (1995). Measurement and Assement in Teaching. Seventh Edition. New York: MacMillan Publishing Company 
Marzano, R.J., Pickering, D, Mctighe, J. 1994. Assessing Student Outcomes: Performance Assessment Using the Dimensions of Learning Model. Alexandria: Association for Supervision and Curriculum Development.

Musnir, D. N. A. 2000. Arah Pendidikan Nasional dalam Perspektif Historis dalam Menggagas Paradigma Baru Pendidikan : Demokratisasi, Otonomi, Civil Society, Globalisasi. Sindhunata (Ed). Yogyakarta:Kanisius.

Nitko, A. (2001). Educational Assessment of Students (4 ${ }^{\text {th }}$ ed.). Upper Saddle River, NJ: Person

NRC (National Research Council). 2000. Inquiry and The National Science Education Standars: A. Guide for Teaching and Learning. Washington: National Academy Press.

Popham, W.James. 1994. Classroom assessment : what teachers need to know. Boston: Allyn and Bacon

Ronis, Diane. 2007. Bran-Compatible Assessments (second edition). California : A sage publications company.

R. Robertson. 1992. Globalization: Social Theory and Global Culture. London: Sage Publications.

Santrock, John W. 2008. Psikologi Pendidikan, Edisi Kedua. Jakarta:

Kencana.Tri Darmiyati. 2008. Pengaruh Globalisasi Terhadap NilaiNilai Nasionalisme.

http://www.wikimu.com/News/DisplayNews.aspx?id=7124. Diakses 21 Pebruari 2011.

Tilaar, H.A.R. 2004. Paradigma Baru Pendidikan Nasional. Jakarta : PT. Rineka Cipta

Worthen, B. 1993. Critical Issues That Will Determine The Future of Alternative Assessment. Phi Delta Kappan

Y.Dedy Pradipto. 2007. Belajar Sejati VS Kurikulum Nasional: Kontestasi Kekuasaan dalamPendidikan Dasar. Yogyakarta: Kanisius. 